\title{
Synthesis, Characterization, Anticancer, and Antioxidant Studies of Ru(III) Complexes of Monobasic Tridentate Schiff Bases
}

\author{
Ikechukwu P. Ejidike and Peter A. Ajibade \\ Department of Chemistry, Faculty of Science and Agriculture, University of Fort Hare, P.B. X1314, Alice 5700, South Africa \\ Correspondence should be addressed to Peter A. Ajibade; pajibade@ufh.ac.za
}

Received 3 March 2016; Revised 28 April 2016; Accepted 5 June 2016

Academic Editor: Claudio Pettinari

Copyright (C) 2016 I. P. Ejidike and P. A. Ajibade. This is an open access article distributed under the Creative Commons Attribution License, which permits unrestricted use, distribution, and reproduction in any medium, provided the original work is properly cited.

\begin{abstract}
Mononuclear $\mathrm{Ru}(\mathrm{III})$ complexes of the type $\left[\mathrm{Ru}(\mathrm{LL}) \mathrm{Cl}_{2}\left(\mathrm{H}_{2} \mathrm{O}\right)\right]\left(\mathrm{LL}=\right.$ monobasic tridentate Schiff base anion: $(1 Z)-N^{\prime}-(2-\{(E)-[1-(2$, 4-dihydroxyphenyl)ethylidene] amino\}ethyl)- $N$-phenylethanimidamide [DAE], 4-[(1E)- $N$ - $\{2$ - [(Z)-(4-hydroxy-3-methoxybenzylidene)amino] ethyl $\}$ ethanimidoyl]benzene-1,3-diol [HME], 4-[(1E)-N-\{2-[(Z)-(3,4-dimethoxybenzylidene)amino]ethyl $\}$ ethanimidoyl]benzene-1,3-diol [MBE], and $N-(2-\{(E)$-[1-(2,4-dihydroxyphenyl)ethylidene]amino\}ethyl)benzenecarboximidoyl chloride [DEE]) were synthesized and characterized using the microanalytical, conductivity measurements, electronic spectra, and FTIR spectroscopy. IR spectral studies confirmed that the ligands act as tridentate chelate coordinating the metal ion through the azomethine nitrogen and phenolic oxygen atom. An octahedral geometry has been proposed for all $\mathrm{Ru}(\mathrm{III})$-Schiff base complexes. In vitro anticancer studies of the synthesized complexes against renal cancer cells (TK-10), melanoma cancer cells (UACC-62), and breast cancer cells (MCF-7) was investigated using the Sulforhodamine $\mathrm{B}$ assay. $\left[\mathrm{Ru}(\mathrm{DAE}) \mathrm{Cl}_{2}\left(\mathrm{H}_{2} \mathrm{O}\right)\right]$ showed the highest activity with $\mathrm{IC}_{50}$ valves of $3.57 \pm 1.09,6.44 \pm 0.38$, and $9.06 \pm 1.18 \mu \mathrm{M}$ against MCF-7, UACC-62, and TK-10, respectively, order of activity being TK-10 < UACC-62 < MCF-7. The antioxidant activity by DPPH and ABTS inhibition assay was also examined. Scavenging ability of the complexes on DPPH radical can be ranked in the following order: $\left[\mathrm{Ru}(\mathrm{DEE}) \mathrm{Cl}_{2}\left(\mathrm{H}_{2} \mathrm{O}\right)\right]>\left[\mathrm{Ru}\left(\mathrm{HME}^{\mathrm{C}} \mathrm{Cl} \mathrm{C}_{2}\left(\mathrm{H}_{2} \mathrm{O}\right)\right]>\right.$ $\left[\mathrm{Ru}(\mathrm{DAE}) \mathrm{Cl}_{2}\left(\mathrm{H}_{2} \mathrm{O}\right)\right]>\left[\mathrm{Ru}(\mathrm{MBE}) \mathrm{Cl}_{2}\left(\mathrm{H}_{2} \mathrm{O}\right)\right]$.
\end{abstract}

\section{Introduction}

Coordination chemistry of transition metal Schiff base complexes possessing $\mathrm{N}, \mathrm{O}$, and $\mathrm{S}$-donor atoms has received consideration over the past few decades, due to the imperative roles these compounds have played in a variety of biochemical procedures like haloperoxidation [1], insulin mimicking $[2,3]$, fixation of nitrogen [4], inhibition of cancer growth, and prophylaxis against carcinogenesis $[5,6]$. A huge variety of carbonyl compounds $(>\mathrm{C}=\mathrm{O})$ and amines $\left(\mathrm{R}-\mathrm{NH}_{2}\right)$ have been exploited in the preparation of Schiff bases [7, 8]. The reactivity of aldehyde compounds is generally faster than those of the ketones in condensation reaction, thereby resulting in the formation of Schiff bases with a centre that are less steric than the ketone's, relatively unstable and freely polymerizable [9]. This important attribute of Schiff base ligands offers prospects for prompting substrate chirality and metal centred electronic factor tuning and improving the solubility and steadiness of either homogeneous or heterogeneous catalysts [10-12].
Schiff bases have shown an interesting application as an active corrosion inhibitor that is established on their capability to spontaneously form a monolayer upon the surface to be glazed [13], as it is a type of interaction existing between an inhibitor and a metal surface known as chemisorption [14]. It is interesting to note that several commercial inhibitors contain amines and aldehydes, but seemingly because of the presence of $>\mathrm{C}=\mathrm{N}$ bond, this makes Schiff bases function more resourcefully in many ways [15]. Stabilization of metal ions in various oxidation states and monitoring their reactivity for catalytic applications have been linked to Schiff bases [16]. The nitrogen-oxygen Schiff bases geometry largely relies on the diamine structural unit, nature of the ancillary ligand, and the central metal ion [17]. Schiff base-transition metal complexes have been known to be one of the most modifiable and comprehensively studied systems [18] with applications in clinical and analytical fields $[19,20]$. Antioxidants derived from metal Schiff base ligand combinations have received current attention for their capability to safeguard living 
systems and cells from impairment caused by oxidative stress or free radicals [21].

DNA binding, cleavage potentials, scavenging potentials, and anticancer investigations of Schiff base-ruthenium(III) complexes have been accounted for [22]. Synthesis, spectral, redox, catalytic, and biological action investigation of mononuclear $\mathrm{Ru}(\mathrm{III})$-Schiff base structures are reported [23]. 2,2'-Bipyridine and tetradentate Schiff base ancillary ligands of mixed-ligand $\mathrm{Ru}(\mathrm{II})$ complexes have been reported for their electrochemical and $\mathrm{Na}^{+}$binding properties [24]. Catalytic and growth inhibitory activities of $\mathrm{Ru}(\mathrm{III})$ mixed ligand complexes of 2-hydroxy-1-naphthylideneimines have been reported [25].

In this study, we report the synthesis, characterization, free radical scavenging, and anticancer studies of four mononuclear ruthenium(III) complexes of Schiff bases derived from $2^{\prime}, 4^{\prime}$-dihydroxyacetophenone and ethylenediamine as the bridging ligand with RCHO moiety alongside their radicals scavenging action on 1,1-diphenyl-2-picrylhydrazyl (DPPH) and 2,2' -azino-bis(3-ethylbenzothiazoline-6sulfonic acid) (ABTS) and antiproliferative potentials. The Schiff base ligands containing $\mathrm{N}_{2} \mathrm{O}$ type tridentate partitions were utilized for the synthesis of the mononuclear ruthenium(III)-Schiff base complexes (Scheme 1).

\section{Experimental}

2.1. Chemicals and Instrumentations. All reagents used were of analytical grade and used as purchased commercially. Ethylenediamine, $N, N^{\prime}$-dimethylformamide (DMF) and ascorbic acid (Vit. C) were received from Merck, $2^{\prime}, 4^{\prime}$ dihydroxyacetophenone and $\mathrm{RuCl}_{3} \cdot 3 \mathrm{H}_{2} \mathrm{O}$ were obtained from Aldrich. 1,1-Diphenyl-2-picrylhydrazyl (DPPH), 2,2' azinobis-3-ethylbenzothiazoline-6-sulfonic acid (ABTS), butylated hydroxytoluene (BHT), and rutin hydrate were received from Sigma Chemical Co. (St. Louis, MO, USA). Elemental analysis was carried out using Perkin-Elmer elemental analyzer. IR spectra were recorded on an FT-IR spectrometer: Perkin-Elmer System (Spectrum 2000) via $\mathrm{KBr}$ disk method was used for the IR spectra analysis. Freshly prepared DMF solutions of about $10^{-3} \mathrm{M}$ containing $\mathrm{Ru}(\mathrm{III})$ complexes gave the molar conductance at room temperature with Crison EC-Meter Basic 30+ conductivity cell. Electronic absorption spectra ranging from 200 to $900 \mathrm{~nm}$ were recorded on a Perkin-Elmer Lambda-25 spectrophotometer. Stuart melting point (SMP 11) was used for the melting points. Four $\mathrm{N}_{2} \mathrm{O}$ type tridentate ligands, $(1 Z)-N^{\prime}-(2-\{(E)-[1-(2,4-$ dihydroxyphenyl)ethylidene] amino\} ethyl)- $N$-phenylethanimidamide [DAE], 4-[(1E)-N-\{2-[(Z)-(4-hydroxy-3-methoxybenzylidene)amino] ethyl\}ethanimidoyl]benzene-1,3diol [HME], 4-[(1E)-N-\{2-[(Z)-(3,4-dimethoxybenzylidene)amino] ethyl $\}$ ethanimidoyl]benzene-1,3-diol [MBE], and $N$-(2-\{(E)-[1-(2,4-dihydroxyphenyl)ethylidene]amino\}ethyl)benzenecarboximidoyl chloride [DEE], were synthesized and reported previously [26].

2.2. Preparation of the Tridentate Schiff Bases (DAE, $H M E, \quad M B E$, and DEE). Ethylenediamine (0.015 mol) dissolved in $20 \mathrm{~mL}$ of alcohol was slowly added to $2^{\prime}, 4^{\prime}$ dihydroxyacetophenone $(0.015 \mathrm{~mol})$ dissolved in same alcohol $(30 \mathrm{~mL})$ and allowed to stir for 60 minutes at room temperature and then followed by drop-wise addition of appropriate aldehyde (RCHO, $15 \mathrm{mmol}$ ) dissolved in $30 \mathrm{~mL}$ alcohol for 20 minutes time interval at room temperature and further stirred for 120 minutes. The mixture was left standing with continuous stirring for approximately 36 hours at room temperature, after which the desired tridentate compounds were filtered and washed with ethanol to give crystalline solid. The crude product was recrystallized from warm ethanol. The products were dried in the vacuum at $50^{\circ} \mathrm{C}$ overnight to give analytically pure products in good yields $(64.2 \%$ to $73.8 \%)$.

2.3. Synthesis of Ru(III)-Tridentate Schiff Base Complexes. $\mathrm{Ru}$ (III) complexes were prepared by adding $(0.5 \mathrm{mmol})$ ethanol solution of ruthenium(III) chloride to a warm ethanolic solution $(0.5 \mathrm{mmol})$ of [DAE]/[HME]/[MBE]/ [DEE], respectively. The colour of the solutions changed immediately, magnetically stirred and kept under reflux for 6 hours. The precipitated solids were filtered by suction from the reaction medium, washed with ethanol and then with diethyl ether, and dried over anhydrous calcium chloride. The yields were about 55.7-61.9\%. The synthesis of the complexes is explained in Scheme 1.

\subsubsection{Synthesis of $\left[\mathrm{OHC}_{6} \mathrm{H}_{3} \mathrm{OH}: \mathrm{C}\left(\mathrm{CH}_{3}\right): \mathrm{N}\left(\mathrm{C}_{2} \mathrm{H}_{4}\right) \mathrm{N}: \mathrm{C}\left(\mathrm{CH}_{3}\right)\right.$ : $\left.\mathrm{NHC}_{6} \mathrm{H}_{5} \mathrm{RuCl}_{2}\left(\mathrm{H}_{2} \mathrm{O}\right)\right]$}

[Ru(DAE) $\left.\mathrm{Cl}_{2}\left(\mathrm{H}_{2} \mathrm{O}\right)\right] \cdot \mathrm{H}_{2} \mathrm{O}$. Dark-green solid; Yield: $156.6 \mathrm{mg}$ (60.4\%); F. Wt: 518.38 g; Anal. Calcd. for $\mathrm{C}_{18} \mathrm{H}_{24} \mathrm{~N}_{3} \mathrm{O}_{4} \mathrm{RuCl}_{2}$ (\%): C 41.71, H 4.67, N 8.11; Found (\%): C 41.43, H 4.54, N 8.29; IR (KBr) $v_{\max } / \mathrm{cm}^{-1}: 3436(\mathrm{O}-\mathrm{H}), 1621(\mathrm{C}=\mathrm{N}), 1242,1170$ (C-O), $520(\mathrm{Ru}-\mathrm{N}), 438$ (Ru-O); UV-Vis (DMF): $\lambda_{\max } / \mathrm{nm}$ $\left(\mathrm{cm}^{-1}\right)$ : 281 (35 587), 310 (32 258), 391 (25 576), 452 (22 124), 525 (19 048), 613 (16 313); Decomp. Temp, ${ }^{\circ} \mathrm{C}, 238-239^{\circ} \mathrm{C} ; \Lambda_{\mu}$ : $31.8 \mu \mathrm{Scm}^{-1}$.

\subsubsection{Synthesis of $\left[\mathrm{OHC}_{6} \mathrm{H}_{3} \mathrm{OH}: \mathrm{C}\left(\mathrm{CH}_{3}\right): \mathrm{N}\left(\mathrm{C}_{2} \mathrm{H}_{4}\right) \mathrm{N}\right.$ : $\mathrm{CH}$ : $\left.\mathrm{C}_{6} \mathrm{H}_{3} \mathrm{OHOCH}_{3} \mathrm{RuCl}_{2}\left(\mathrm{H}_{2} \mathrm{O}\right)\right]$}

[Ru(HME) $\left.\mathrm{Cl}_{2}\left(\mathrm{H}_{2} \mathrm{O}\right)\right] \cdot \mathrm{H}_{2} \mathrm{O}$. Darkish-green Solid; Yield: $165.7 \mathrm{mg}$ (61.9\%); F. Wt: $535.37 \mathrm{~g}$; Anal. Calcd. for $\mathrm{C}_{18} \mathrm{H}_{23} \mathrm{~N}_{2} \mathrm{O}_{6} \mathrm{RuCl}_{2}$ (\%): C 40.38, $\mathrm{H}$ 4.33, N 5.23; Found (\%): C 40.58, H 4.21, N 5.44; IR (KBr) $v_{\max } / \mathrm{cm}^{-1}: 3422(\mathrm{O}-\mathrm{H}), 1637$ $(\mathrm{C}=\mathrm{N}), 1245,1173$ (C-O), $485(\mathrm{Ru}-\mathrm{N}), 437$ (Ru-O); UV-Vis (DMF): $\lambda_{\text {max }} / \mathrm{nm}\left(\mathrm{cm}^{-1}\right): 277$ (36101), 309 (32363), 381 (26 247), 393 (25 446), 513 (19 493), 623 (16 051); Decomp. Temp, ${ }^{\circ} \mathrm{C}, 218-219^{\circ} \mathrm{C} ; \Lambda_{\mu}: 30.5 \mu \mathrm{Scm}^{-1}$.

\subsubsection{Synthesis of $\left[\mathrm{OHC}_{6} \mathrm{H}_{3} \mathrm{OH}: \mathrm{C}\left(\mathrm{CH}_{3}\right): \mathrm{N}\left(\mathrm{C}_{2} \mathrm{H}_{4}\right) \mathrm{N}\right.$ : $\left.\mathrm{CH}: \mathrm{C}_{6} \mathrm{H}_{5}\left(\mathrm{OCH}_{3}\right)_{2} \mathrm{RuCl}_{2}\left(\mathrm{H}_{2} \mathrm{O}\right)\right]$}

[Ru(MBE) $\left.\mathrm{Cl}_{2}\left(\mathrm{H}_{2} \mathrm{O}\right)\right] \cdot \mathrm{H}_{2} \mathrm{O}$. Darkish-green Solid; Yield: $160.4 \mathrm{mg}$ (58.4\%); F. Wt: $549.39 \mathrm{~g}$; Anal. Calcd. for $\mathrm{C}_{19} \mathrm{H}_{25} \mathrm{~N}_{2} \mathrm{O}_{6} \mathrm{RuCl}_{2}$ (\%): $\mathrm{C}$ 41.54, $\mathrm{H}$ 4.59, $\mathrm{N}$ 5.10; Found 


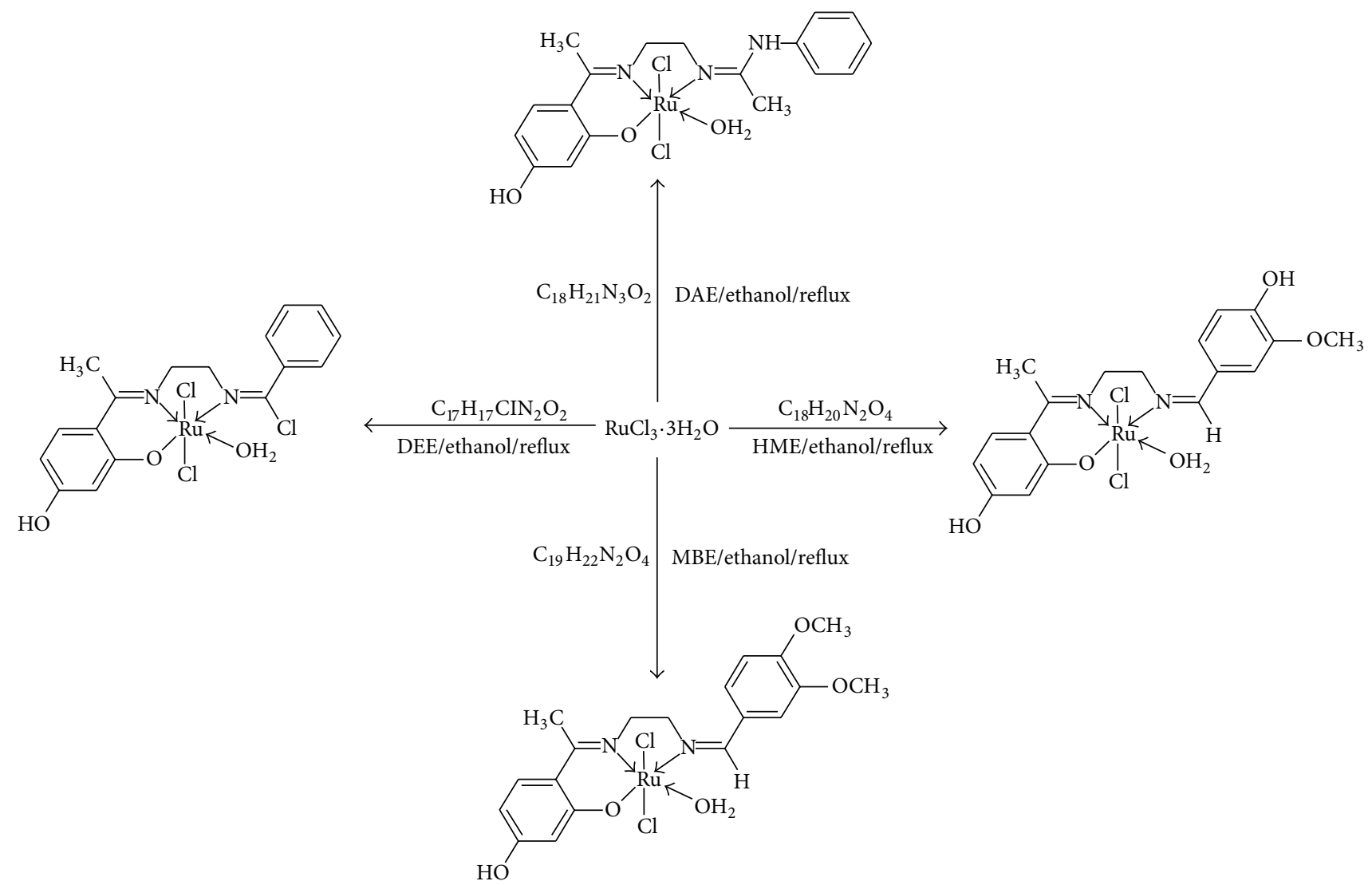

Scheme 1: Structure of mononuclear ruthenium(III)-Schiff base complexes.

(\%): C 41.29, H 4.32, N 4.98; IR (KBr) $v_{\max } / \mathrm{cm}^{-1}$ : 3435 (O$\mathrm{H}), 1639(\mathrm{C}=\mathrm{N}), 1244,1171(\mathrm{C}-\mathrm{O}), 548(\mathrm{Ru}-\mathrm{N}), 475(\mathrm{Ru}-\mathrm{O})$; UV-Vis (DMF): $\lambda_{\max } / \mathrm{nm}\left(\mathrm{cm}^{-1}\right): 277$ (36101), 311 (32155), 380 (26 316), 393 (25 446), 510 (19 608), 623 (16 051); Decomp. Temp, ${ }^{\circ} \mathrm{C}, 226-227^{\circ} \mathrm{C} ; \Lambda_{\mu}: 30.1 \mu \mathrm{Scm}^{-1}$.

\subsubsection{Synthesis of $\left[\mathrm{OHC}_{6} \mathrm{H}_{3} \mathrm{OH}: \mathrm{C}\left(\mathrm{CH}_{3}\right): \mathrm{N}\left(\mathrm{C}_{2} \mathrm{H}_{4}\right) \mathrm{N}: \mathrm{C}(\mathrm{Cl})\right.$ : $\left.\mathrm{C}_{6} \mathrm{H}_{5} \mathrm{RuCl}_{2}\left(\mathrm{H}_{2} \mathrm{O}\right)\right]$}

[Ru(DEE) $\left.\mathrm{Cl}_{2}\left(\mathrm{H}_{2} \mathrm{O}\right)\right] \cdot \mathrm{H}_{2} \mathrm{O}$. Dark-green Solid; Yield: $145.9 \mathrm{mg}$ (55.7\%); F. Wt: $523.79 \mathrm{~g}$; Anal. Calcd. for $\mathrm{C}_{17} \mathrm{H}_{20} \mathrm{~N}_{2} \mathrm{O}_{4} \mathrm{RuCl}_{3}$ (\%): C 38.98, H 3.85, N 5.35; Found (\%): C 39.11, H 3.67, N 5.11; IR (KBr) $v_{\max } / \mathrm{cm}^{-1}: 3416(\mathrm{O}-\mathrm{H}), 1617(\mathrm{C}=\mathrm{N}), 1243,1169$ (C-O), 475 (Ru-N), 436 (Ru-O); UV-Vis (DMF): $\lambda_{\max } / \mathrm{nm}$ $\left(\mathrm{cm}^{-1}\right): 275$ (31364), 306 (32 680), 385 (25 974), 521 (19 231), 632 (15 823); Decomp. Temp, ${ }^{\circ} \mathrm{C}, 228-229^{\circ} \mathrm{C} ; \Lambda_{\mu}: 38.8 \mu \mathrm{Scm}^{-1}$.

2.4. In Vitro Antiproliferative Activity. The potentials of the $\mathrm{Ru}$ (III)-tridentate Schiff base complexes to interfere with the growth of TK-10 renal cell line, UACC-62 melanoma cell line, and MCF-7 breast cell lines were determined by SRB assay as previously described [22]. 3-19 passages of MCF-7, TK-10, and UACC- 62 cell lines with plating densities of 7-10 000 cells per well were precultured into 96 -well microtitre plates for $24 \mathrm{~h}$ at $37^{\circ} \mathrm{C}$ with $95 \%$ air, $5 \% \mathrm{CO}_{2}$, and $100 \%$ relative humidity in RPMI medium, supplemented with $5 \%$ fetal bovine serum
(FBS), $50 \mu \mathrm{g} \mathrm{mL}^{-1}$ (gentamicin), and $2 \mathrm{mM} \mathrm{L-glutamine} \mathrm{[27].}$ The compounds were dissolved in DMSO and treated with the cells after $24 \mathrm{~h}$ and diluted in RPMI medium giving rise to 5 concentrations comprising $0.01,0.1,0,10$, and $100 \mu \mathrm{M}$.

Wells containing culture medium were used as control while the wells containing complete culture medium with no cells were used as the blanks. Parthenolide was used as the standard drug in this study. The plates were then incubated for $48 \mathrm{~h}$ after the addition of the compounds. Viable cells were fixed to the bottom of each well with cold $50 \%$ trichloroacetic acid, washed, dried, and dyed by SRB. The unbounded dye was separated, while the protein-bound dye was extracted with $10 \mathrm{mM}$ Tris base and multiwell spectrophotometer at the wavelength $540 \mathrm{~nm}$ was used for its optical density determination. $\mathrm{IC}_{50}$ values were determined by plotting the percentage viability against concentration of compounds on a logarithmic graph to obtain $50 \%$ of cell growth inhibition relative to the control.

\subsection{Antioxidant Assay}

2.5.1. Scavenging Activity of 1,1-Diphenyl-2-picrylhydrazyl $(D P P H)$ Radical. The antioxidant activity of the prepared $\mathrm{Ru}(\mathrm{III})$ complexes was studied using spectrophotometer by 1,1-diphenyl-2-picrylhydrazyl (DPPH) method. This compound is known as a stable readily accessible free radical, with solubility in methanol giving a purple solution, and 
when reacted with antioxidant species changes to an equivalent light yellow colour. The radical scavenging potentials of the complexes with $\mathrm{DPPH}$ radical were evaluated as described [22]. $1 \mathrm{~mL}$ solution of the compounds in DMF with concentrations ranging from 100 to $500 \mu \mathrm{g} / \mathrm{mL}$ was mixed thoroughly with equivalent amount of $0.4 \mathrm{mM} \mathrm{DPPH}$ in methanol; the mixtures were then allowed to react in the dark for half an hour. Measurement of the mixture absorbance was achieved spectrophotometrically at $517 \mathrm{~nm}$. Vitamin C and rutin were used as the standard drugs. All test analysis was carried out in triplicate. The ability of the ruthenium compounds to scavenge DPPH radical was calculated via the following equation:

$\mathrm{DPPH}$ radical scavenging activity (\%)

$$
\begin{aligned}
= & \frac{\text { Absorbance of control }- \text { Absorbance of sample }}{\text { Absorbance of control }} \\
& \times 100 \text {. }
\end{aligned}
$$

2.5.2. ABTS: 2,2'-Azino-bis(3-ethylbenzothiazoline-6-sulfonic acid) Radical Scavenging Assay. ABTS scavenging ability of the $\mathrm{Ru}(\mathrm{III})$-tridentate Schiff base complexes adopted a described method [28]. $7 \mathrm{mM}$ ABTS solution and $2.4 \mathrm{mM}$ potassium persulfate solution in equal amounts $(1: 1)$ were used for working solution preparation and allowed to react in the dark for $12 \mathrm{~h}$ at room temperature. An absorbance of $0.706 \pm 0.001$ units at $734 \mathrm{~nm}$ required for the analysis was obtained by diluting $1 \mathrm{~mL} \mathrm{ABTS}{ }^{+}$solution. Test samples $(1 \mathrm{~mL})$ were mixed with $1 \mathrm{~mL}$ of the $\mathrm{ABTS}^{+}$solution, and absorbance was read spectrophotometrically at $734 \mathrm{~nm}$. The test samples' ABTS scavenging capacity alongside standard drugs was evaluated. Triplicate analysis was carried out. The percentage inhibition of ABTS radical scavenging activity was obtained following a previous report [28].

\section{Results and Discussion}

3.1. Synthesis and Characterization. The obtained compounds were of coloured powders, stable in atmosphere with a general formula: $\left[\mathrm{Ru}(\mathrm{LL}) \mathrm{Cl}_{2}\left(\mathrm{H}_{2} \mathrm{O}\right)\right](\mathrm{LL}=$ monobasic tridentate Schiff base anion: DAE, HME, MBE, and DEE). They were prepared by treating $\left[\mathrm{RuCl}_{3} \cdot 3 \mathrm{H}_{2} \mathrm{O}\right]$ with the corresponding Schiff base in an equal mole ratio in alcohol as depicted in the Scheme 1. All the complexes are darkgreen and sparingly soluble in general organic solvents but soluble in polar aprotic solvent such as DMF and DMSO; the melting point analysis showed that the $\mathrm{Ru}(\mathrm{III})$ complexes were decomposing before melting. The physicoanalytical data collected for the compounds are in agreement with the structural formulae proposed, thus confirming the suggested mononuclear composition for the $\mathrm{Ru}(\mathrm{III})$ complexes (Scheme 1).

3.2. Molar Conductivity Measurements. The molar conductance of the synthesized $\mathrm{Ru}(\mathrm{III})$ complexes was measured in $\mathrm{DMF}$ at $10^{-3} \mathrm{M}$ solution. The values were found to be in the range of $30.1-38.8 \mu \mathrm{Scm}^{-1}$ suggesting the nonelectrolytic nature of the complexes in solution $[22,29]$.

3.3. Infrared Spectra. Valuable evidence concerning the environment of the functional group attached to the ruthenium atom has been obtained from the FTIR spectra. The IR spectra of the ligands, when compared with those of the newly synthesized complexes, confirm the coordination of $\mathrm{N}_{2} \mathrm{O}$ type tridentate ligands to the ruthenium ion. The classification was achieved by comparing the spectra of the ligands with those originating from the coordination between ruthenium(III) metal ion and the active sites. The Schiff bases showed the broad bands in the $3462-3477 \mathrm{~cm}^{-1}$ range attributable to the $v(\mathrm{OH}) \mathrm{cm}^{-1}$ vibration. Ligand infrared spectra showed that a band at $1605-1619 \mathrm{~cm}^{-1}$ is attributed to $\nu(\mathrm{C}=\mathrm{N})$ stretching of the azomethine group based on earlier reports [30]. This $\nu(C=N)$ shift to $1617-1639 \mathrm{~cm}^{-1}$ in all the complexes by about $5-23 \mathrm{~cm}^{-1}$ signifies the participation of azomethine nitrogen in the coordination sphere with the ruthenium(III) ion for all the complexes [21, 31]. A medium band that corresponds to phenolic oxygen atom $v(\mathrm{C}-\mathrm{O})$ is observed at 1167 and $1245 \mathrm{~cm}^{-1}$ for the free ligands.

The higher shifting of $v(\mathrm{C}-\mathrm{O})$ stretching vibrations as observed in the ruthenium(III) complexes spectra suggests that the phenolic $\mathrm{OH}$ group of Schiff base, DAE, HME, $\mathrm{MBE}$, and DEE, is involved in coordination with ruthenium ion after deprotonation $[32,33]$. Seemingly, the DAE, HME, $\mathrm{MBE}$, and DEE ligands act as a tridentate chelating compound, coordinating to the metal ion via the two nitrogen atoms of the azomethine group as well as $\mathrm{O}$ atom of phenolic group $[21,25]$. This is further supported by the displacement of $\nu(\mathrm{O}-\mathrm{H})$ in the range $3462-3477 \mathrm{~cm}^{-1}$ in all the complexes. The presence of coordinated water gave a broad band that appeared in the regions $3416-3436$ and $813-851 \mathrm{~cm}^{-1}$; this can be due to $v(\mathrm{O}-\mathrm{H})$ stretching and $v(\mathrm{O}-\mathrm{H})$ rocking vibrations, respectively, which further confirms the presence of nonligand assignable to the rocking mode of water $[28,34]$. New weak nonligand bands that are not found in the DAE, HME, $\mathrm{MBE}$, and DEE ligands appeared in the ranges $475-548 \mathrm{~cm}^{-1}$ and $436-475 \mathrm{~cm}^{-1}$ in the complexes spectra attributed to $\nu(\mathrm{Ru}-\mathrm{N})$ and $\nu(\mathrm{Ru}-\mathrm{O})$ vibrations, respectively $[35,36]$. A band ranging from $311-346 \mathrm{~cm}^{-1}$ appeared in the spectra of the $\mathrm{Ru}$ (III)-Schiff base complexes indicating the presence of two chloride ions in trans position around ruthenium centre [3740].

3.4. Electronic Absorption Spectra Studies. The UV-Vis spectra of the $\mathrm{Ru}(\mathrm{III})$-Schiff base complexes in DMF solutions were recorded at room temperature ranging from 200 to $900 \mathrm{~nm}$. The nature of DAE, HME, MBE, and DEE ligands field around the ruthenium ion was obtained from the electronic spectra. The free ligands showed absorption bands within the range of $277-393 \mathrm{~nm}$ attributable to $\pi^{*} \leftarrow \pi$ and $\pi^{*} \leftarrow n$ transitions relating the benzene ring (Figure 1 ). The shifting of these bands in the complexes spectra followed the participation of the imine group nitrogen and phenolic group oxygen in bonding $[22,25]$. Ground state of ruthenium(III) is ${ }^{2} \mathrm{~T}_{2 \mathrm{~g}}$, where initial excited doublet levels in order of increasing 


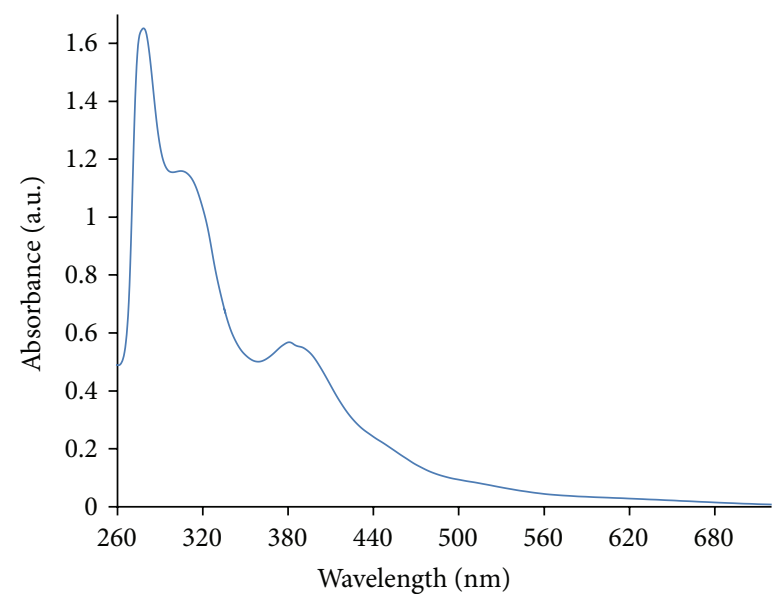

(a)

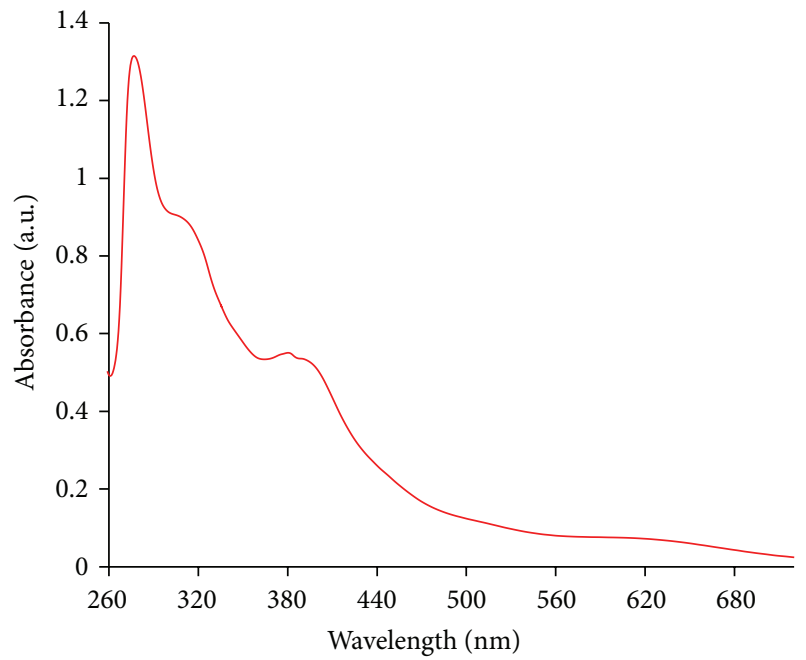

(c)

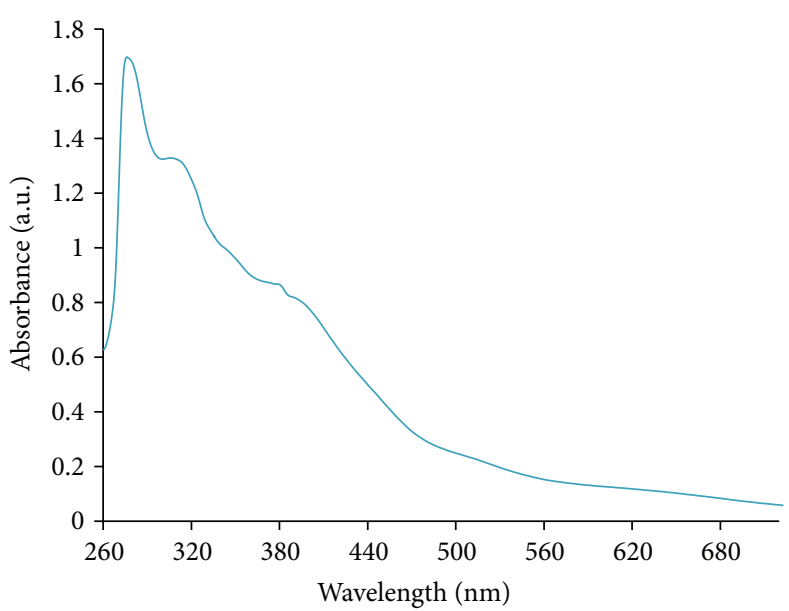

(b)

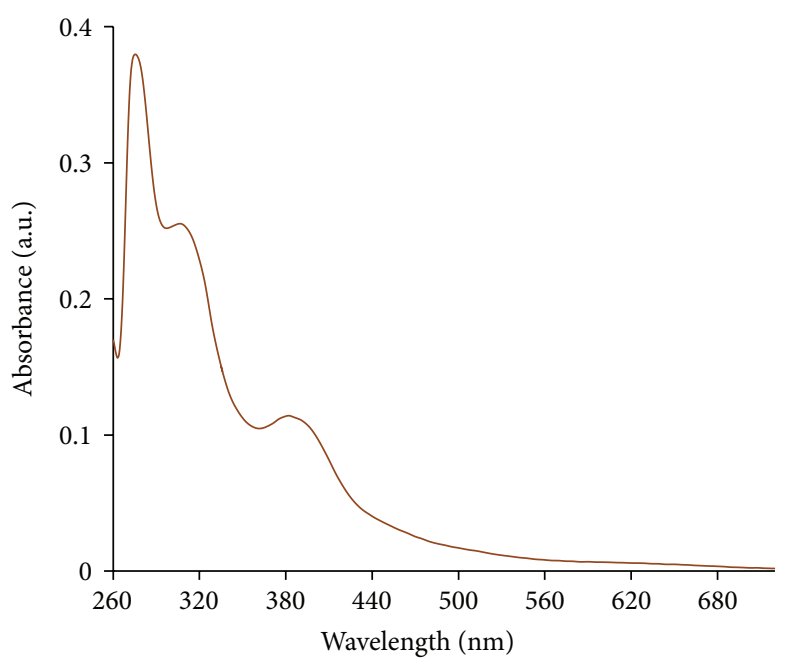

(d)

FIgURE 1: Electronic absorption spectra of the $\mathrm{Ru}(\mathrm{III})$ complexes: $\left[\mathrm{Ru}(\mathrm{MBE}) \mathrm{Cl}_{2}\left(\mathrm{H}_{2} \mathrm{O}\right)\right] ;$ (d) $\left[\mathrm{Ru}(\mathrm{DEE}) \mathrm{Cl}_{2}\left(\mathrm{H}_{2} \mathrm{O}\right)\right]$.

energy are ${ }^{2} \mathrm{~A}_{2 \mathrm{~g}}$ and ${ }^{2} \mathrm{~T}_{1 \mathrm{~g}}$, arising from $\mathrm{t}_{2 \mathrm{~g}}^{4} \mathrm{e}_{\mathrm{g}}^{1}$ configuration [41].

$\mathrm{Ru}^{3+}$ ion, with a $\mathrm{d}^{5}$ electronic configuration, possesses high oxidizing properties and large crystal field parameter. Also, charge transfer bands of the type $\mathrm{L}_{\pi y} \rightarrow \mathrm{T}_{2 \mathrm{~g}}$ were noticeable within low energy region, obscuring weaker bands that is due to d-d transitions [22, 25]. The extinction coefficient bands around $613-632 \mathrm{~nm}$ regions are found to be low when compared to the charge transfer bands. These bands have been assigned to ${ }^{2} \mathrm{~T}_{2 \mathrm{~g}} \rightarrow{ }^{2} \mathrm{~A}_{2 \mathrm{~g}}$ transition and are in agreement with the assignment made for similar octahedral ruthenium(III) complexes [42, 43]. Absorption bands within the $452-525 \mathrm{~nm}$ regions were assigned to the charge transfer transitions [22, 44]. Overall, the absorption spectra of the $\mathrm{Ru}(\mathrm{III})$-Schiff base complexes are typical of octahedral environment about the ruthenium(III) ions [22].

3.5. Antiproliferative Activity. Investigation into the structure-activity relationship of the isolated $\mathrm{Ru}(\mathrm{III})-\mathrm{N}_{2} \mathrm{O}$ Schiff base complexes with respect to different functional groups on the ligands used for ruthenium ion complex formation has been conducted via antiproliferative studies. Three of the $\mathrm{Ru}(\mathrm{III})$-Schiff base compounds alongside parthenolide were subjected to cell lines tests at different sample concentrations ranging from 0.01 to $100 \mu \mathrm{M}$ towards renal cancer cell (TK10), melanoma cancer cell (UACC-62), and breast cancer cell (MCF-7). The cancer cell lines were incubated for $48 \mathrm{~h}$, followed by the addition of the compounds of various concentrations via Sulforhodamine B (SRB) assay [22].

The ruthenium(III) compounds and standard drug (parthenolide) $\mathrm{IC}_{50}$ values are presented in Table 1 and revealed that the test samples showed significant inhibition against the tested cell lines. Figures 2-4 represent the cell viability percentages of ruthenium(III)-Schiff base complexes and parthenolide drug against TK-10, UACC-62, and MCF7 cell lines, at different concentrations of ruthenium(III) compounds or parthenolide. A high level of antiproliferative potentials against the studied cell lines was exhibited by parthenolide in accordance with earlier reports [45]. The obtained results revealed that treatment of cell lines with 
TABLE 1: In vitro antiproliferative studies of Ru(III)-Schiff base complexes against TK-10, UACC-62, and MCF-7 cell lines.

\begin{tabular}{lcccr}
\hline Compounds & Molecular formula & \multicolumn{3}{c}{ Anticancer activity $\mathrm{IC}_{50}(\mu \mathrm{M}) 48 \mathrm{~h}$} \\
& & TK-10 & UACC-62 & MCF-7 \\
\hline$\left[\mathrm{Ru}(\mathrm{DAE}) \mathrm{Cl}_{2}\left(\mathrm{H}_{2} \mathrm{O}\right)\right]$ & $\mathrm{C}_{18} \mathrm{H}_{24} \mathrm{~N}_{3} \mathrm{O}_{4} \mathrm{RuCl}_{2}$ & $9.06 \pm 1.18$ & $6.44 \pm 0.38$ & $3.57 \pm 1.09$ \\
{$\left[\mathrm{Ru}(\mathrm{HME}) \mathrm{Cl}_{2}\left(\mathrm{H}_{2} \mathrm{O}\right)\right]$} & $\mathrm{C}_{18} \mathrm{H}_{23} \mathrm{~N}_{2} \mathrm{O}_{6} \mathrm{RuCl}_{2}$ & $41.09 \pm 4.44$ & $6.31 \pm 1.47$ & $4.88 \pm 1.28$ \\
{$\left[\mathrm{Ru}(\mathrm{DEE}) \mathrm{Cl}_{2}\left(\mathrm{H}_{2} \mathrm{O}\right)\right]$} & $\mathrm{C}_{17} \mathrm{H}_{20} \mathrm{~N}_{2} \mathrm{O}_{4} \mathrm{RuCl}_{3}$ & $13.10 \pm 2.81$ & $5.14 \pm 1.09$ & $3.43 \pm 1.48$ \\
Parthenolide & $\mathrm{C}_{15} \mathrm{H}_{20} \mathrm{O}_{3}$ & $0.50 \pm 1.43$ & $0.89 \pm 2.18$ & $0.44 \pm 2.02$ \\
\hline
\end{tabular}

* Standard cytotoxin drug: cell lines were treated with different concentrations of the compounds to achieve $50 \%$ inhibition of the culture growth when cultured for $48 \mathrm{~h}$. Value represents mean \pm SD of three independent experimentations.

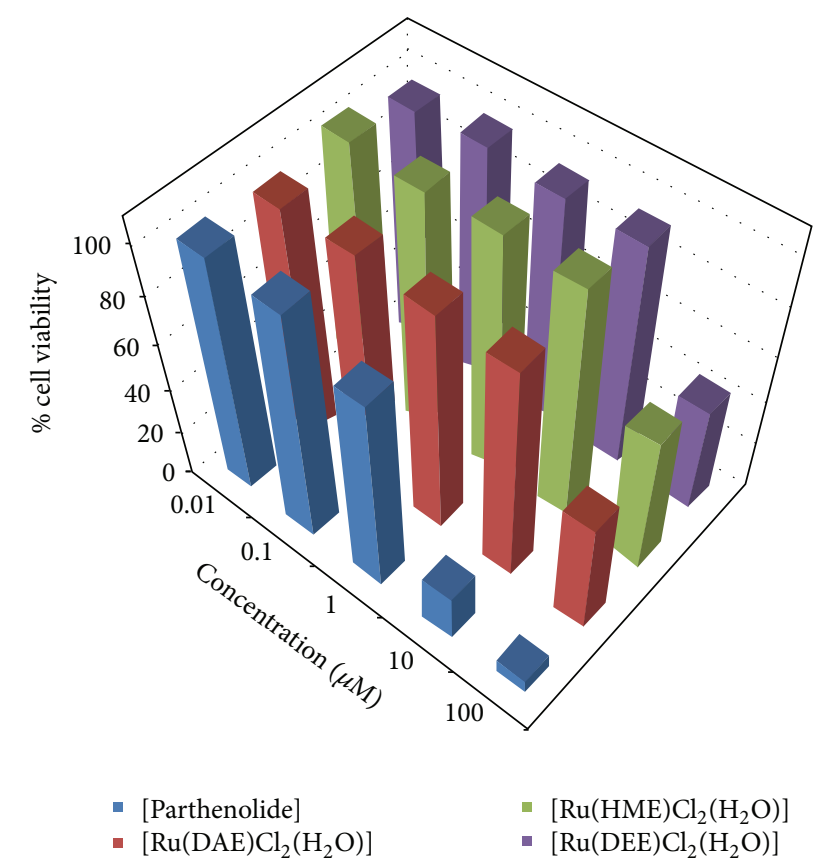

FIGURE 2: In vitro antiproliferative activity of Ru(III) complexes and parthenolide against human breast cancer cell line (MCF-7).

different concentrations of $\mathrm{Ru}(\mathrm{III})$-Schiff base complexes efficiently affected cell viability towards MCF-7 cells, as displayed in Figures 2-4 and Table 1. The Ru(III) compounds exhibited low to strong in vitro antiproliferative activities against the selected cell lines as compared to the standard drug (parthenolide). [Ru(DAE) $\left.\mathrm{Cl}_{2}\left(\mathrm{H}_{2} \mathrm{O}\right)\right],\left[\mathrm{Ru}(\mathrm{HME}) \mathrm{Cl}_{2}\left(\mathrm{H}_{2} \mathrm{O}\right)\right]$, and $\left[\mathrm{Ru}(\mathrm{DEE}) \mathrm{Cl}_{2}\left(\mathrm{H}_{2} \mathrm{O}\right)\right]$ induced more efficient cell death with $\mathrm{IC}_{50}$ values of $3.57 \pm 1.09,4.88 \pm 1.28$, and $3.43 \pm 1.48 \mu \mathrm{M}$, respectively, towards human breast cancer cell (MCF-7) cells than other investigated cell lines, compared with $\mathrm{IC}_{50}$ values of $0.44 \pm 2.02 \mu \mathrm{M}$ MCF-7, for the standard cytotoxin drug parthenolide.

The order of activity of the complexes against human melanoma cancer cell (UACC-62) is as follows: $\left[\mathrm{Ru}(\mathrm{DEE}) \mathrm{Cl}_{2}\left(\mathrm{H}_{2} \mathrm{O}\right)\right]>\left[\mathrm{Ru}(\mathrm{HME}) \mathrm{Cl}_{2}\left(\mathrm{H}_{2} \mathrm{O}\right)\right]>$ $\left[\mathrm{Ru}(\mathrm{DAE}) \mathrm{Cl}_{2}\left(\mathrm{H}_{2} \mathrm{O}\right)\right]$. With respect to previous report by Shier [46], compounds exhibiting $\mathrm{IC}_{50}$ activity ranging from 10 to $25 \mu \mathrm{M}$ are referred to as weak anticancer drugs, while those with $\mathrm{IC}_{50}$ action between 5 and $10 \mu \mathrm{M}$ are moderate, and the compounds possessing activity less than $(<) 5.00 \mu \mathrm{M}$

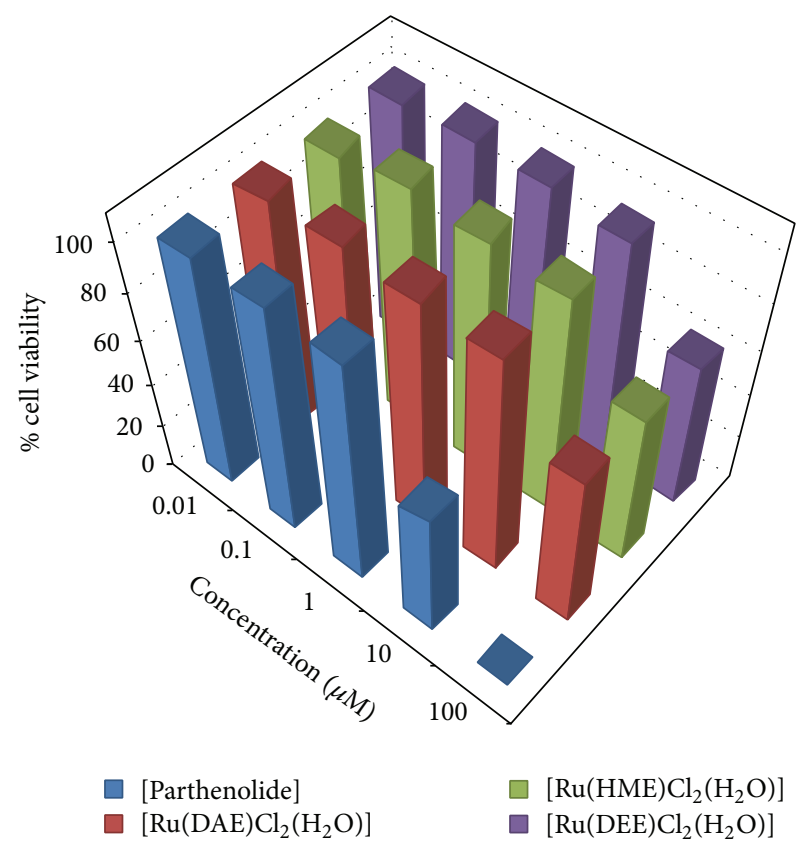

FIGURE 3: In vitro antiproliferative activity of $\mathrm{Ru}(\mathrm{III})$ complexes and parthenolide against human melanoma cancer cell (UACC-62).

are considered as strong agents. Thus, the $\mathrm{Ru}(\mathrm{III})$ complexes exhibited a weak to strong activity against the investigated cancer cell lines with the following order of activity: MCF$7>$ UACC-62 > TK-10. However, $\left[\mathrm{Ru}(\mathrm{DAE}) \mathrm{Cl}_{2}\left(\mathrm{H}_{2} \mathrm{O}\right)\right]$ showed the highest antiproliferative activity with $\mathrm{IC}_{50}$ valves of $3.57 \pm 1.09,6.44 \pm 0.38$, and $9.06 \pm 1.18 \mu \mathrm{M}$ for MCF-7, UACC-62, and TK-10, respectively. The biochemical activity could be due to the methoxy, alkyl, chloride group substituents and bridge spacer: ethylenediamine, which could have played a vital role in antiproliferative potentials of the $\mathrm{Ru}$ (III)- $\mathrm{N}_{2} \mathrm{O}$ Schiff base complexes. In vitro anticancer activity of the synthesized $\mathrm{Ru}(\mathrm{III})$ complexes in this study was compared with $\mathrm{Ru}$ complexes reported by other authors and found that $\left[\mathrm{Ru}(\mathrm{DAE}) \mathrm{Cl}_{2}\left(\mathrm{H}_{2} \mathrm{O}\right)\right],\left[\mathrm{Ru}(\mathrm{HME}) \mathrm{Cl}_{2}\left(\mathrm{H}_{2} \mathrm{O}\right)\right]$, and $\left[\mathrm{Ru}(\mathrm{DEE}) \mathrm{Cl}_{2}\left(\mathrm{H}_{2} \mathrm{O}\right)\right]$ complexes exhibited higher antitumor activities. $\left[\mathrm{RuCl}(\mathrm{CO})\left(\mathrm{PPh}_{3}\right) \mathrm{L}\right]$ reported by Raja et al. [47] against human cervical carcinoma cell line, (HeLa) after exposure for $48 \mathrm{~h}$, gave an $\mathrm{IC}_{50}$ value in the range of $31.6 \mu \mathrm{M}$ and $\left[\mathrm{RuCl}_{2}\left(\mathrm{AsPh}_{3}\right) \mathrm{L}\right]$ with an $\mathrm{IC}_{50}$ value of $37.8 \mu \mathrm{M}$ [48]. Raju et al. [43] reported ruthenium(III) Schiff base complexes of the type $\left[\mathrm{RuX}_{2}\left(\mathrm{PPh}_{3}\right)_{2}(\mathrm{~L})\right]$ (where $\mathrm{X}=\mathrm{Cl}$ or 


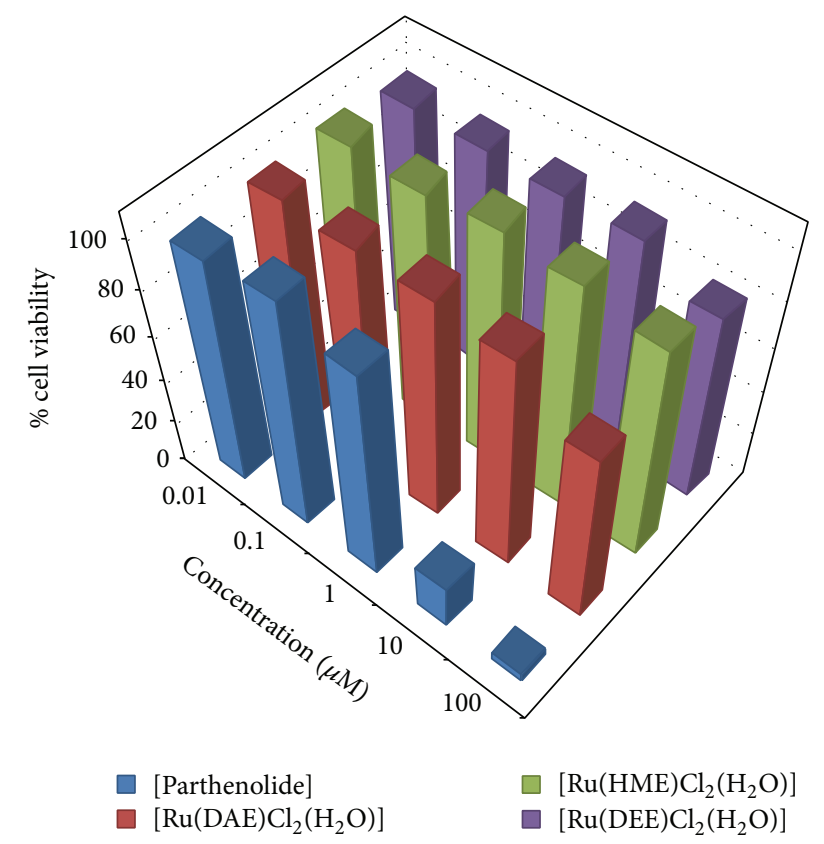

FIGURE 4: In vitro antiproliferative activity of $\mathrm{Ru}(\mathrm{III})$ complexes and parthenolide against human renal cancer cell (TK-10).

$\mathrm{Br} ; \mathrm{L}=$ monobasic bidentate ligand) complex to have $\mathrm{IC}_{50}$ value in the range of $45.2 \mu \mathrm{M}$.

3.6. Antioxidant Capacity. Different antioxidant techniques and modifications have been put forward to evaluate antioxidants reactivity and functionality in foods and biological systems as a means of checkmating variety of pathological activities such as cellular injury and aging process; these damaging occurrences are caused by free radicals. Hence, two free radicals were used for in vitro antioxidants activities of the test samples in this study, namely, 1,1-diphenyl-2-picrylhydrazyl (DPPH) and 2,2' -azino-bis(3ethylbenzothiazoline-6-sulfonic acid) (ABTS).

3.6.1. DPPH Radical Scavenging Assay. The activity of antioxidants on DPPH radical is believed to be centred on their ability to donate hydrogen [22]. DPPH has been a stable free radical, with the ability to accept hydrogen radical or an electron and then become a stable molecule [49].

The mode of rummaging the DPPH radical has extensively been used to appraise antioxidant activities of test samples in a moderately short period of time compared to other procedures [49]. The reduction in the DPPH radical capability is calculated by the decrease in its absorbance at $517 \mathrm{~nm}$ prompted by antioxidants [50]. The reduction of DPPH radical intensity in this study is due to the interaction of $\mathrm{Ru}(\mathrm{III})$ complexes with radical and as such scavenging the radicals by hydrogen donation (Scheme 2). The DPPH activities by the $\mathrm{Ru}(\mathrm{III})-\mathrm{N}_{2} \mathrm{O}$ Schiff base complexes exhibit strong electron donating power when compared to the standards: ascorbic acid and rutin as displayed in Figure 5. The calculated $\mathrm{IC}_{50}$ and its corresponding $R^{2}$ (correlation

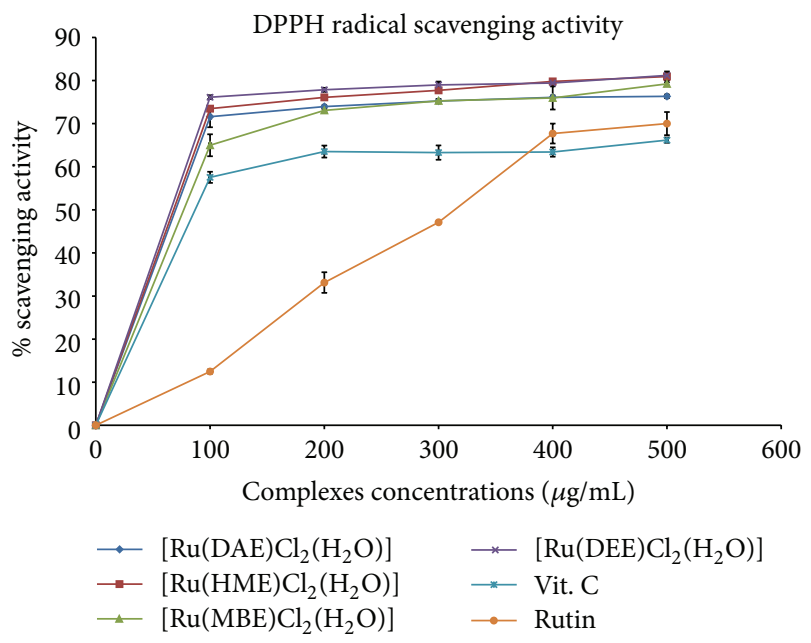

FIGURE 5: DPPH scavenging potential of Ru(III)-Schiff base complexes.

coefficient) values of $\mathrm{Ru}(\mathrm{III})$ compounds are listed in Table 2. Compounds [Ru(DAE) $\left.\mathrm{Cl}_{2}\left(\mathrm{H}_{2} \mathrm{O}\right)\right], \quad\left[\mathrm{Ru}(\mathrm{HME}) \mathrm{Cl}_{2}\left(\mathrm{H}_{2} \mathrm{O}\right)\right]$, $\left[\mathrm{Ru}(\mathrm{MBE}) \mathrm{Cl}_{2}\left(\mathrm{H}_{2} \mathrm{O}\right)\right]$, and $\left[\mathrm{Ru}(\mathrm{DEE}) \mathrm{Cl}_{2}\left(\mathrm{H}_{2} \mathrm{O}\right)\right]$ with an $\mathrm{IC}_{50}$ value of $1.60 \pm 0.68,1.54 \pm 0.44,1.63 \pm 1.05$, and $1.51 \pm 0.50 \mu \mathrm{M}$, respectively, exhibited higher activity against DPPH than the commercially available Vit. $\mathrm{C}$ and rutin (standard); however, $\left[\mathrm{Ru}(\mathrm{DEE}) \mathrm{Cl}_{2}\left(\mathrm{H}_{2} \mathrm{O}\right)\right]$ showed the highest activity of all investigated ruthenium(III) samples with an $\mathrm{IC}_{50}$ value of $1.51 \pm 0.50 \mu \mathrm{M}$.

Scavenging ability of the test samples on the $\mathrm{DPPH}$ radical can be ranked in the following order: $\left[\mathrm{Ru}(\mathrm{DEE}) \mathrm{Cl}_{2}\left(\mathrm{H}_{2} \mathrm{O}\right)\right]>\left[\mathrm{Ru}(\mathrm{HME}) \mathrm{Cl}_{2}\left(\mathrm{H}_{2} \mathrm{O}\right)\right]>$ $\left[\mathrm{Ru}(\mathrm{DAE}) \mathrm{Cl}_{2}\left(\mathrm{H}_{2} \mathrm{O}\right)\right]>\left[\mathrm{Ru}(\mathrm{MBE}) \mathrm{Cl}_{2}\left(\mathrm{H}_{2} \mathrm{O}\right)\right]>$ [Vit. C] $>$ [rutin]. The scavenging effect of the DAE, HME, MBE, and DEE ligands is lower as compared to their corresponding $\mathrm{Ru}$ (III) complexes, owing to the coordination of the organic molecules to the $\mathrm{Ru}^{3+}$ ion. It is further supported by the observed discolouration from purple DPPH radical solution to yellow solution showing scavenging of the DPPH radicals by hydrogen donation (Scheme 2). Hence, these complexes could be effective therapeutic agent's preparation for the treatment of chronic conditions such as cardiovascular, neurodegenerative, and arteriosclerosis diseases [21].

3.6.2. 2,2'-Azino-bis(3-ethylbenzothiazoline-6-sulfonic acid) Radical Scavenging Activity. To further confirm the synthesized $\mathrm{Ru}(\mathrm{III})-\mathrm{N}_{2} \mathrm{O}$ Schiff base complexes antiradical potential, we examined the ABTS assay in this study. A well-known protonated radical like $2,2^{\prime}$-azinobis-3-ethylbenzothiazoline6-sulfonic acid (ABTS) possesses characteristic absorbance maxima at $734 \mathrm{~nm}$ and decreases with the scavenging of the proton radicals [51]. The assay measures radical scavenging by electron donation. The outcome of $\mathrm{Ru}(\mathrm{III})-\mathrm{N}_{2} \mathrm{O}$ Schiff base complexes alongside the standard drugs on ABTS radical is presented in Table 2. At $734 \mathrm{~nm}$, the absorbance of active ABTS* solution noticeably declined upon the addition of different concentrations of ruthenium(III) samples; the same trend was also observed for the standard drugs: butylated 


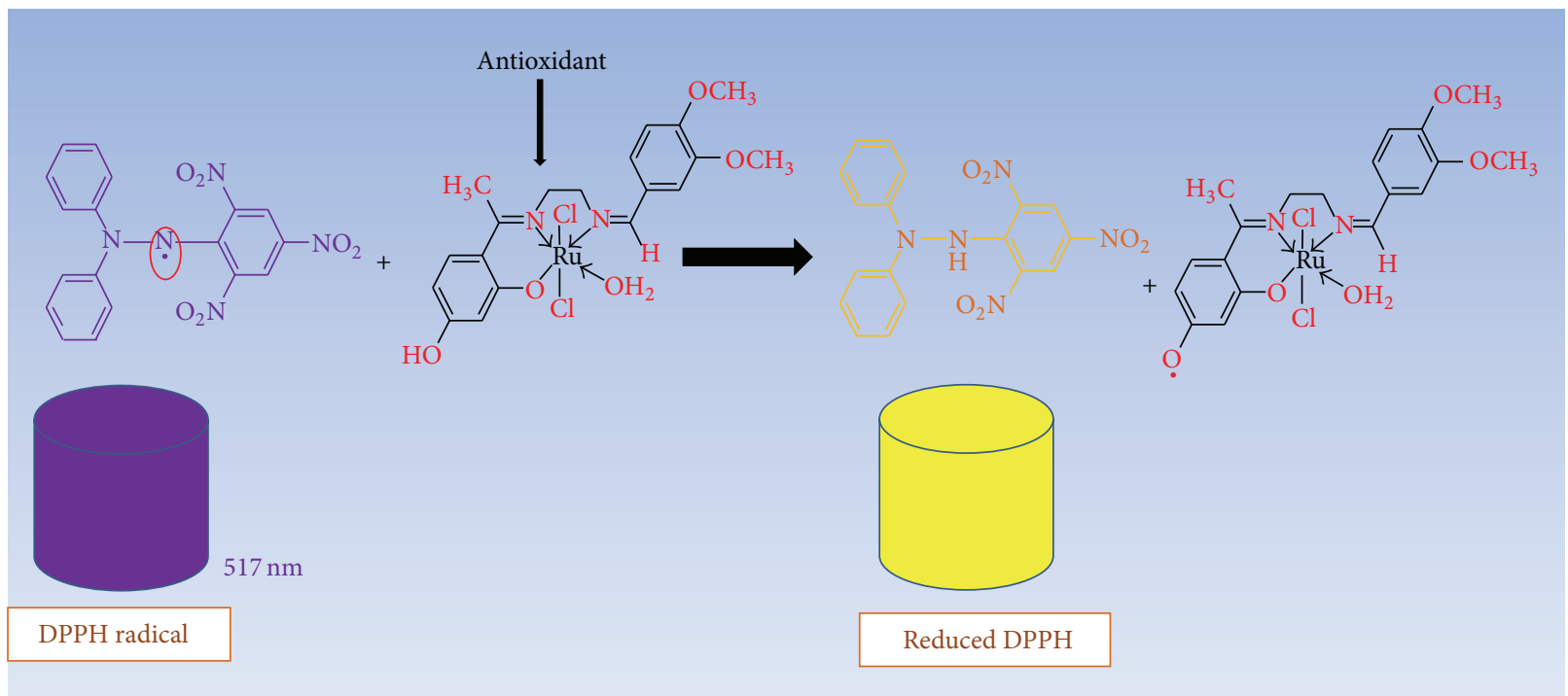

Scheme 2: Conversion of DPPH* (purple) to its corresponding hydrazine form (yellow) by the addition of Ru(III) compounds to DPPH* due to proton transfer.

TABLE 2: Radical scavenging abilities ( $\left.\mathrm{IC}_{50} \pm \mathrm{SD}, \mu \mathrm{M}\right)$ of $\mathrm{Ru}(\mathrm{III})$-Schiff base complexes and standard drugs.

\begin{tabular}{lcccc}
\hline \multirow{2}{*}{ Compounds } & \multicolumn{2}{c}{ DPPH radical scavenging activity } & \multicolumn{2}{c}{ ABTS radical scavenging activity } \\
& $\mathrm{IC}_{50}(\mu \mathrm{M})$ & $R^{2}$ & $\mathrm{IC}_{50}(\mu \mathrm{M})$ & 0.959 \\
\hline $\mathrm{Ru}(\mathrm{DAE}) \mathrm{Cl}_{2}\left(\mathrm{H}_{2} \mathrm{O}\right)$ & $1.60 \pm 0.68$ & 0.965 & $3.30 \pm 0.89$ \\
$\mathrm{Ru}(\mathrm{HME}) \mathrm{Cl}_{2}\left(\mathrm{H}_{2} \mathrm{O}\right)$ & $1.54 \pm 0.44$ & 0.974 & $4.27 \pm 1.17$ \\
$\mathrm{Ru}(\mathrm{MBE}) \mathrm{Cl}_{2}\left(\mathrm{H}_{2} \mathrm{O}\right)$ & $1.63 \pm 1.05$ & 0.991 & $3.30 \pm 1.48$ \\
$\mathrm{Ru}(\mathrm{DEE}) \mathrm{Cl}_{2}\left(\mathrm{H}_{2} \mathrm{O}\right)$ & $1.51 \pm 0.50$ & 0.963 & $3.24 \pm 0.93$ & 0.808 \\
Rutin $^{*}$ & $2.52 \pm 1.60$ & 0.798 & $2.83 \pm 1.84$ & 0.857 \\
Vit. C $^{*}$ & $1.92 \pm 1.07$ & 0.978 & - & 0.983 \\
BHT $^{*}$ & - & - & $1.64 \pm 1.54$ & 0.919 \\
\hline
\end{tabular}

$n=3, X \pm \mathrm{SEM} ; \mathrm{IC}_{50}$ : growth inhibitory concentration; when the inhibition of the tested compounds was $50 \%$, the tested compound concentration was $\mathrm{IC}_{50}$. $R^{2}$ : correlation coefficient. ${ }^{*}$ Standards.

hydroxytoluene (BHT) and rutin hydrate with the percentage inhibition displayed in Figure 6.

The efficacy of the tested samples in quenching ATBS* radicals in the system was observed at $100 \mu \mathrm{g} / \mathrm{mL}$, the lowest concentration, and $\mathrm{Ru}(\mathrm{III})$ complexes exhibited higher ABTS $\%$ inhibition than the standards. $\left[\mathrm{Ru}(\mathrm{DEE}) \mathrm{Cl}_{2}\left(\mathrm{H}_{2} \mathrm{O}\right)\right]$ complex exhibited the highest ABTS scavenging activity amongst the studied ruthenium(III) complexes with an $\mathrm{IC}_{50}$ value of $3.24 \pm 0.93 \mu \mathrm{M}$ and $0.855 R^{2}$ (correlation coefficient) as listed in Table 2 while complexes of $\left[\mathrm{Ru}(\mathrm{DAE}) \mathrm{Cl}_{2}\left(\mathrm{H}_{2} \mathrm{O}\right)\right]$, $\left[\mathrm{Ru}(\mathrm{HME}) \mathrm{Cl}_{2}\left(\mathrm{H}_{2} \mathrm{O}\right)\right]$, and $\left[\mathrm{Ru}(\mathrm{MBE}) \mathrm{Cl}_{2}\left(\mathrm{H}_{2} \mathrm{O}\right)\right]$ had an $\mathrm{IC}_{50}$ value of $3.30 \pm 0.89,4.27 \pm 1.17$, and $3.30 \pm 1.48 \mu \mathrm{M}$, respectively.

The ABTS scavenging activity pattern of the complexes is ranked in the following order: $\left[\mathrm{Ru}(\mathrm{HME}) \mathrm{Cl}_{2}\left(\mathrm{H}_{2} \mathrm{O}\right)\right.$ ] $<\left[\mathrm{Ru}(\mathrm{MBE}) \mathrm{Cl}_{2}\left(\mathrm{H}_{2} \mathrm{O}\right)\right]=\left[\mathrm{Ru}(\mathrm{DAE}) \mathrm{Cl}_{2}\left(\mathrm{H}_{2} \mathrm{O}\right)\right]<$ $\left[\mathrm{Ru}(\mathrm{DEE}) \mathrm{Cl}_{2}\left(\mathrm{H}_{2} \mathrm{O}\right)\right]$. With this result, the antiradical studies showed that the synthesised $\mathrm{Ru}(\mathrm{III})-\mathrm{N}_{2} \mathrm{O}$ Schiff base complexes may be useful in developing therapeutic agent for averting cell oxidative damage and as radicals chain terminator. This is because various free radicals generated in the system often lead to cancer, cellular injury, aging process, and cardiovascular diseases [21].

\section{Conclusion}

In this study, we present the synthesis of $\mathrm{Ru}(\mathrm{III})$ Schiff base complexes formulated as $\left[\mathrm{Ru}(\mathrm{LL}) \mathrm{Cl}_{2}\left(\mathrm{H}_{2} \mathrm{O}\right)\right](\mathrm{LL}=\mathrm{DAE}$, HME, MBE, and DEE). The complexes were characterized using the microanalytical, conductance, electronic, and vibrational spectral analysis. FTIR spectral data showed that the ligand acts as tridentate chelating ligand, coordinating through azomethine nitrogen and phenol oxygen atom. The microanalyses were in conformity with the proposed structures. Conductance measurements showed the complexes to be nonelectrolytes in DMF. Octahedral structures were assigned to these complexes based on the elemental and spectral information. In vitro antiproliferative studies of the $\mathrm{Ru}$ (III) complexes gave a weak to strong inhibition against the studied cancer cell lines, with the following activity order: MCF-7 > UACC-62 > TK-10. Significantly, 


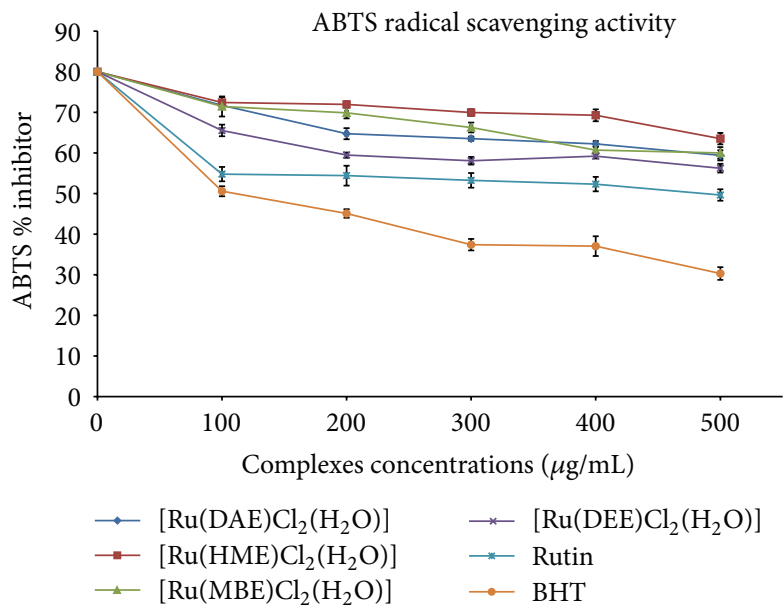

FIGURE 6: ABTS rummaging activity of $\mathrm{Ru}(\mathrm{III})$-Schiff base complexes.

further investigation on the compounds free radical scavenging properties revealed that $\mathrm{Ru}(\mathrm{III})$-Schiff base complexes possessed considerable antioxidant activities. The outcome from DPPH and ABTS inhibition studies revealed that the compounds are proficient in donating electron or hydrogen atom and subsequently terminate the chain reactions in a dose-dependent pattern. Scavenging ability of the test samples on the DPPH radicals can be ranked in the following order: $\left[\mathrm{Ru}(\mathrm{DEE}) \mathrm{Cl}_{2}\left(\mathrm{H}_{2} \mathrm{O}\right)\right]>\left[\mathrm{Ru}(\mathrm{HME}) \mathrm{Cl}_{2}\left(\mathrm{H}_{2} \mathrm{O}\right)\right]>$ $\left[\mathrm{Ru}(\mathrm{DAE}) \mathrm{Cl}_{2}\left(\mathrm{H}_{2} \mathrm{O}\right)\right]>\left[\mathrm{Ru}(\mathrm{MBE}) \mathrm{Cl}_{2}\left(\mathrm{H}_{2} \mathrm{O}\right)\right]$. Thus, $\mathrm{Ru}(\mathrm{III})-$ $\mathrm{N}_{2} \mathrm{O}$ Schiff base complexes showed stronger inhibition of $\mathrm{DPPH}$ at various concentrations.

\section{Competing Interests}

No conflict of interests regarding the publication of this paper is declared by the authors.

\section{Acknowledgments}

The authors acknowledge Govan Mbeki Research and Development Centre (GMRDC), University of Fort Hare, for financial support and IPE acknowledges National Research Foundation and Sasol Inzalo Foundation for the award of Ph.D. scholarship.

\section{References}

[1] A. Butler and J. V. Walker, "Marine haloperoxidases," Chemical Reviews, vol. 93, no. 5, pp. 1937-1944, 1993.

[2] Y. Shechter, I. Goldwaser, M. Mironchik, M. Fridkin, and D. Gefel, "Historic perspective and recent developments on the insulin-like actions of vanadium; toward developing vanadiumbased drugs for diabetes," Coordination Chemistry Reviews, vol. 237, no. 1-2, pp. 3-11, 2003.

[3] A. M. B. Bastos, J. G. da Silva, P. I. S. Maia et al., "Oxovanadium(IV) and (V) complexes of acetylpyridine-derived semicarbazones exhibit insulin-like activity," Polyhedron, vol. 27, no. 6, pp. 1787-1794, 2008.
[4] R. R. Eady, "Current status of structure function relationships of vanadium nitrogenase," Coordination Chemistry Reviews, vol. 237, no. 1-2, pp. 23-30, 2003.

[5] K. H. Thompson, J. H. McNeill, and C. Orvig, "Vanadium compounds as insulin mimics," Chemical Reviews, vol. 99, no. 9, pp. 2561-2572, 1999.

[6] G. Grivani, G. Bruno, H. A. Rudbari, A. D. Khalaji, and P. Pourteimouri, "Synthesis, characterization and crystal structure determination of a new oxovanadium(IV) Schiff base complex: the catalytic activity in the epoxidation of cyclooctene," Inorganic Chemistry Communications, vol. 18, pp. 15-20, 2012.

[7] J. W. Pyrz, A. L. Roe, L. J. Stern, and L. Que Jr., "Model studies of iron-tyrosinate proteins," Journal of the American Chemical Society, vol. 107, no. 3, pp. 614-620, 1985.

[8] M. Tümer, B. Erdogan, H. Köksal, S. Serin, and M. Y. Nutku, "Preparation, spectroscopic characterisation and thermal analyses studies of the $\mathrm{Cu}(\mathrm{II}), \mathrm{Pd}(\mathrm{II})$ and $\mathrm{VO}(\mathrm{IV})$ complexes of some Schiff base ligands," Synthesis and Reactivity in Inorganic and Metal-Organic Chemistry, vol. 28, no. 4, pp. 529-542, 1998.

[9] J. Hine and C. Y. Yeh, "Equilibrium in formation and conformational isomerization of imines derived from isobutyraldehyde and saturated aliphatic primary amines," Journal of the American Chemical Society, vol. 89, no. 11, pp. 2669-2676, 1967.

[10] T. Opstal and F. Verpoort, "Synthesis of highly active ruthenium indenylidene complexes for atom-transfer radical polymerization and ring-opening-metathesis polymerization," Angewandte Chemie -International Edition, vol. 42, no. 25, pp. 28762879, 2003.

[11] B. De Clercq, F. Lefebvre, and F. Verpoort, "Immobilization of multifunctional Schiff base containing ruthenium complexes on MCM-41," Applied Catalysis A: General, vol. 247, no. 2, pp. 345-364, 2003.

[12] A. Gölcü, M. Tümer, H. Demirelli, and R. A. Wheatley, "Cd(II) and $\mathrm{Cu}(\mathrm{II})$ complexes of polydentate Schiff base ligands: synthesis, characterization, properties and biological activity," Inorganica Chimica Acta, vol. 358, no. 6, pp. 1785-1797, 2005.

[13] N. Mishra, K. Poonia, and D. Kumar, "An overview of biological aspects of Schiff base metal complexes," International Journal of Advancements in Research \& Technology, vol. 2, no. 8, pp. 52-66, 2013.

[14] L.-A. H. Allen, L. S. Schlesinger, and B. Kang, "Virulent strains of Helicobacter pylori demonstrate delayed phagocytosis and stimulate homotypic phagosome fusion in macrophages," The Journal of Experimental Medicine, vol. 191, no. 1, pp. 115-127, 2000.

[15] L. A. Calderon, R. C. L. Teles, J. R. S. A. Leite, C. Bloch Jr., S. Astolfi-Filho, and S. M. Freitas, "Serine protease inhibitors from Amazon Leguminosae seeds: purification and preliminary characterization of two chymotrypsin inhibitors from Inga umbratica," Protein and Peptide Letters, vol. 8, no. 6, pp. 485493, 2001.

[16] P. G. Cozzi, "Metal-Salen Schiff base complexes in catalysis: practical aspects," Chemical Society Reviews, vol. 33, no. 7, pp. 410-421, 2004.

[17] T. Katsuki, "Unique asymmetric catalysis of cis- $\beta$ metal complexes of salen and its related Schiff-base ligands," Chemical Society Reviews, vol. 33, no. 7, pp. 437-444, 2004.

[18] I. M. I. Fakhr, N. A. Hamdy, M. A. Radwan, and Y. M. Ahmed, "Synthesis of new bioactive benzothiophene derivatives," Egyptian Journal of Chemistry, vol. 47, pp. 201-215, 2004.

[19] R. A. A. Ammar and A.-N. M. A. Alaghaz, "Synthesis, spectroscopic characterization and potentiometric studies of 
a tetradentate $\left[\mathrm{N}_{2} \mathrm{O}_{2}\right]$ schiff base, N,N'-bis(2-hydroxybenzylidene)-1,1-diaminoethane and its $\mathrm{Co}(\mathrm{II}), \mathrm{Ni}(\mathrm{II}), \mathrm{Cu}(\mathrm{II})$ and $\mathrm{Zn}$ (II) complexes," International Journal of Electrochemical Science, vol. 8, no. 6, pp. 8686-8699, 2013.

[20] A. S. Gaballa, M. S. Asker, A. S. Barakat, and S. M. Teleb, "Synthesis, characterization and biological activity of some platinum(II) complexes with Schiff bases derived from salicylaldehyde, 2-furaldehyde and phenylenediamine," Spectrochimica Acta Part A: Molecular and Biomolecular Spectroscopy, vol. 67, no. 1, pp. 114-121, 2007.

[21] I. P. Ejidike and P. A. Ajibade, "Transition metal complexes of symmetrical and asymmetrical Schiff bases as antibacterial, antifungal, antioxidant, and anticancer agents: progress and prospects," Reviews in Inorganic Chemistry, vol. 35, no. 4, pp. 191-224, 2015.

[22] I. P. Ejidike and P. A. Ajibade, "Synthesis, characterization, and in vitro antioxidant and anticancer studies of ruthenium(III) complexes of symmetric and asymmetric tetradentate Schiff bases," Journal of Coordination Chemistry, vol. 68, no. 14, pp. 2552-2564, 2015.

[23] N. P. Priya, S. Arunachalam, A. Manimaran, D. Muthupriya, and C. Jayabalakrishnan, "Mononuclear Ru(III) Schiff base complexes: synthesis, spectral, redox, catalytic and biological activity studies," Spectrochimica Acta Part A: Molecular and Biomolecular Spectroscopy, vol. 72, no. 3, pp. 670-676, 2009.

[24] L. Mishra, R. Prajapati, and K. K. Pandey, "Mixed-ligand Ru(II) complexes with $2,2^{\prime}$-bipyridine and tetradentate Schiff bases auxiliary ligands: Synthesis, physico-chemical study, DFT analysis, electrochemical and $\mathrm{Na}^{+}$binding properties," Spectrochimica Acta-Part A: Molecular and Biomolecular Spectroscopy, vol. 70, no. 1, pp. 79-85, 2008.

[25] G. Venkatachalam and R. Ramesh, "Catalytic and biological activities of $\mathrm{Ru}(\mathrm{III})$ mixed ligand complexes containing $\mathrm{N}, \mathrm{O}$ donor of 2-hydroxy-1-naphthylideneimines," Spectrochimica Acta Part A: Molecular and Biomolecular Spectroscopy, vol. 61, no. 9, pp. 2081-2087, 2005.

[26] I. P. Ejidike and P. A. Ajibade, "Synthesis and in vitro anticancer, antibacterial, and antioxidant studies of unsymmetrical Schiff base derivatives of 4-[(1E)-N-(2-aminoethyl)ethanimidoyl]benzene-1,3-diol," Research on Chemical Intermediates, vol. 42, no. 8, pp. 6543-6555, 2016.

[27] K. I. Ansari, I. Hussain, H. K. Das, and S. S. Mandal, "Overexpression of human histone methylase MLL1 upon exposure to a food contaminant mycotoxin, deoxynivalenol," The FEBS Journal, vol. 276, no. 12, pp. 3299-3307, 2009.

[28] I. P. Ejidike and P. A. Ajibade, "Synthesis, characterization and biological studies of metal(II) complexes of (3E)-3-[(2-\{(E)[1-(2,4-Dihydroxyphenyl) ethylidene]amino\}ethyl)imino]-1phenylbutan-1-one schiff base," Molecules, vol. 20, no. 6, pp. 9788-9802, 2015.

[29] C. A. Bolos, A. T. Chaviara, D. Mourelatos et al., "Synthesis, characterization, toxicity, cytogenetic and in vivo antitumor studies of 1,1-dithiolate $\mathrm{Cu}(\mathrm{II})$ complexes with di-, tri-, tetraamines and 1,3-thiazoles. Structure-activity correlation," Bioorganic \& Medicinal Chemistry, vol. 17, no. 8, pp. 3142-3151, 2009.

[30] P. K. Das, N. Panda, and N. K. Behera, "Synthesis, characterization and antimicrobial activities of Schiff base complexes derived from isoniazid and diacetylmonoxime," International Journal of Innovative Science, Engineering \& Technology, vol. 3, no. 1, pp. 42-54, 2016.
[31] L. Mitu, M. Ilis, N. Raman, M. Imran, and S. Ravichandran, "Transition metal complexes of isonicotinoyl-hydrazone-4diphenylaminobenzaldehyde: synthesis, characterization and antimicrobial studies," E-Journal of Chemistry, vol. 9, no. 1, pp. 365-372, 2012.

[32] S. A. Ali, A. A. Soliman, M. M. Aboaly, and R. M. Ramadan, "Chromium, molybdenum and ruthenium complexes of 2hydroxyacetophenone schiff bases," Journal of Coordination Chemistry, vol. 55, no. 10, pp. 1161-1170, 2002.

[33] K. N. Kumar, R. Ramesh, and Y. Liu, "Synthesis, structure and catalytic activity of cycloruthenated carbonyl complexes containing arylazo phenolate ligands," Journal of Molecular Catalysis A: Chemical, vol. 265, no. 1-2, pp. 218-226, 2007.

[34] I. P. Ejidike and P. A. Ajibade, "Synthesis, characterization, antioxidant, and antibacterial studies of some metal(II) complexes of tetradentate schiff base ligand: $(4 E)-4-[(2-\{(E)-[1-$ (2,4-dihydroxyphenyl)ethylidene]amino\} ethyl)imino]pentan2-one," Bioinorganic Chemistry and Applications, vol. 2015, Article ID 890734, 9 pages, 2015.

[35] J. S. Casas, A. Castiñeiras, F. Condori et al., "Diorganotin(IV)promoted deamination of amino acids by pyridoxal: $\mathrm{SnR}_{2}{ }^{2+}$ complexes of pyridoxal $5^{\prime}$-phosphate and of the Schiff base pyridoxal-pyridoxamine (PLPM), and antibacterial activities of PLPM and [SnR $\left.{ }_{2}(\mathrm{PLPM}-2 \mathrm{H})\right](\mathrm{R}=\mathrm{Me}, \mathrm{Et}, \mathrm{Bu}, \mathrm{Ph})$," Polyhedron, vol. 22, no. 1, pp. 53-65, 2003.

[36] P. J. K. Inba, B. Annaraj, S. Thalamuthu, and M. A. Neelakantan, " $\mathrm{Cu}(\mathrm{II}), \mathrm{Ni}(\mathrm{II})$, and $\mathrm{Zn}$ (II) complexes of salan-type ligand containing ester groups: synthesis, characterization, electrochemical properties, and in vitro biological activities," Bioinorganic Chemistry and Applications, vol. 2013, Article ID 439848, 11 pages, 2013.

[37] K. Shanker, R. Rohini, V. Ravinder, P. M. Reddy, and Y.-P. Ho, "Ru(II) complexes of $\mathrm{N}_{4}$ and $\mathrm{N}_{2} \mathrm{O}_{2}$ macrocyclic Schiff base ligands: their antibacterial and antifungal studies," Spectrochimica Acta Part A: Molecular and Biomolecular Spectroscopy, vol. 73, no. 1, pp. 205-211, 2009.

[38] M. Alias, H. Kassum, and C. Shakir, "Synthesis, physical characterization and biological evaluation of Schiff base M(II) complexes," Journal of the Association of Arab Universities for Basic and Applied Sciences, vol. 15, no. 1, pp. 28-34, 2014.

[39] K. Shivakumar, Shashidhar, P. V. Reddy, and M. B. Halli, "Synthesis, spectral characterization and biological activity of benzofuran Schiff bases with $\mathrm{Co}(\mathrm{II}), \mathrm{Ni}(\mathrm{II}), \mathrm{Cu}(\mathrm{II}), \mathrm{Zn}(\mathrm{II})$, $\mathrm{Cd}(\mathrm{II})$ and $\mathrm{Hg}$ (II) complexes," Journal of Coordination Chemistry, vol. 61, no. 14, pp. 2274-2287, 2008.

[40] T. D. Thangadurai and S.-K. Ihm, "Novel bidentate ruthenium(III) Schiff base complexes: synthetic, spectral, electrochemical, catalytic and antimicrobial studies," Transition Metal Chemistry, vol. 29, no. 2, pp. 189-195, 2004.

[41] C. J. Ballhausen, Introduction to Ligand Field Theory, McGarw Hill, New York, NY, USA, 1962.

[42] A. B. P. Lever, Inorganic Electronic Spectroscopy, Elsevier, New York, NY, USA, 2nd edition, 1984.

[43] V. V. Raju, K. P. Balasubramanian, C. Jayabalakrishnan, and V. Chinnusamy, "Synthesis, characterization, antimicrobial activities and DNA-Binding studies of some $\mathrm{Ru}(\mathrm{III})$ complexes of Schiff bases," International Journal of Applied Biology and Pharmaceutical Technology, vol. 3, no. 2, pp. 76-87, 2012.

[44] K. P. Balasubramanian, K. Parameswari, V. Chinnusamy, R. Prabhakaran, and K. Natarajan, "Synthesis, characterization, electro chemistry, catalytic and biological activities of ruthenium(III) complexes with bidentate N, O/S donor ligands," 
Spectrochimica Acta-Part A: Molecular and Biomolecular Spectroscopy, vol. 65, no. 3-4, pp. 678-683, 2006.

[45] A. Ghantous, M. Saikali, T. Rau, H. Gali-Muhtasib, R. Schneider-Stock, and N. Darwiche, "Inhibition of tumor promotion by parthenolide: epigenetic modulation of p21," Cancer Prevention Research, vol. 5, no. 11, pp. 1298-1309, 2012.

[46] W. T. Shier, Mammalian Cell Culture on \$5 a Day: A Lab Manual of Low Cost Methods, University of the Philippines, Los Banos, Calif, USA, 1991.

[47] G. Raja, R. J. Butcher, and C. Jayabalakrishnan, "Studies on synthesis, characterization, DNA interaction and cytotoxicity of ruthenium(II) Schiff base complexes," Spectrochimica Acta Part A: Molecular and Biomolecular Spectroscopy, vol. 94, pp. 210215, 2012.

[48] G. Raja, R. J. Butcher, and C. Jayabalakrishnan, "Synthesis, characterization, DNA binding and cleavage properties and anticancer studies of ruthenium(III) Schiff base complexes," Transition Metal Chemistry, vol. 37, no. 2, pp. 169-174, 2012.

[49] I. Gülçin, Ö. I. Küfrevioglu, M. Oktay, and M. E. Büyükokuroglu, "Antioxidant, antimicrobial, antiulcer and analgesic activities of nettle (Urtica dioica L.)," Journal of Ethnopharmacology, vol. 90, no. 2-3, pp. 205-215, 2004.

[50] M. Viuda-Martos, Y. R. Navajas, E. S. Zapata, J. FernándezLópez, and J. A. Pérez-Álvarez, "Antioxidant activity of essential oils of five spice plants widely used in a Mediterranean diet," Flavour and Fragrance Journal, vol. 25, no. 1, pp. 13-19, 2010.

[51] S. Mathew and T. E. Abraham, "In vitro antioxidant activity and scavenging effects of Cinnamomum verum leaf extract assayed by different methodologies," Food and Chemical Toxicology, vol. 44, no. 2, pp. 198-206, 2006. 

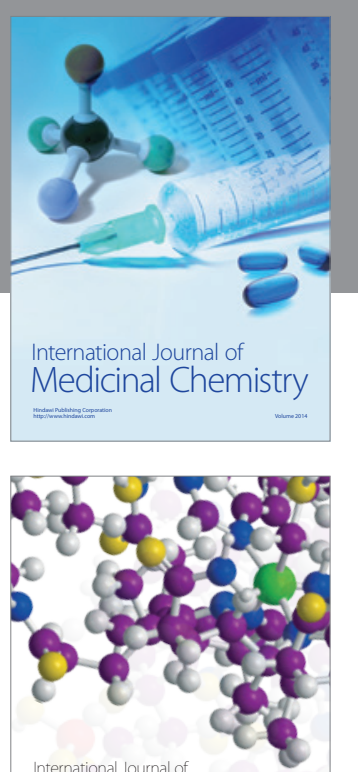

Carbohydrate Chemistry

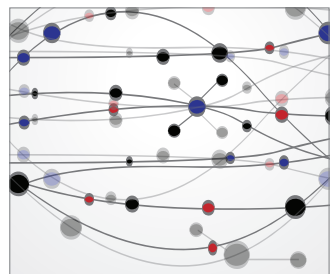

The Scientific World Journal
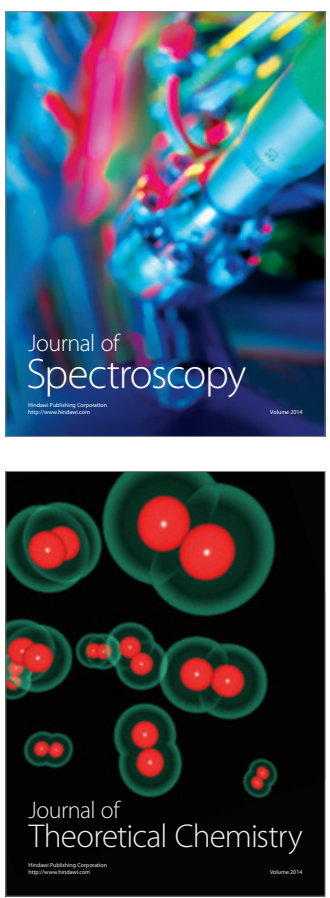
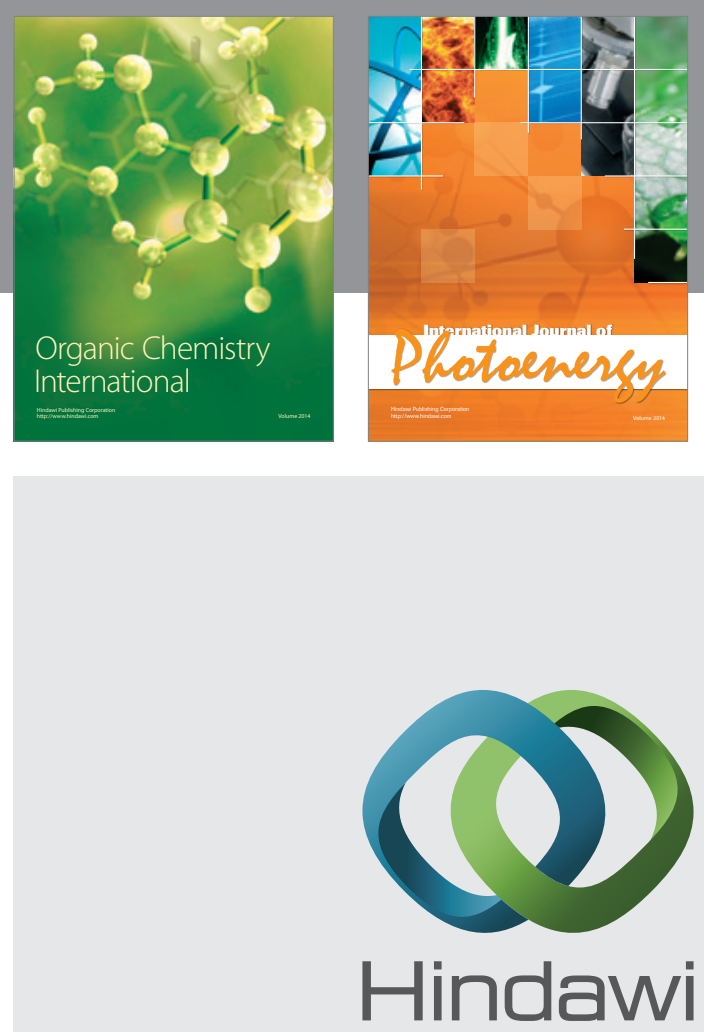

Submit your manuscripts at

http://www.hindawi.com

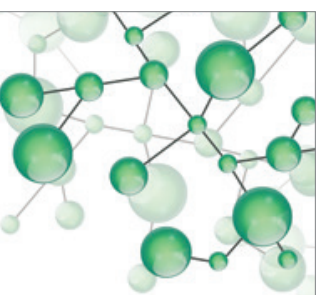

International Journal of

Inorganic Chemistry

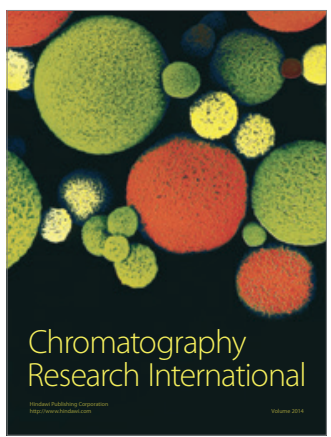

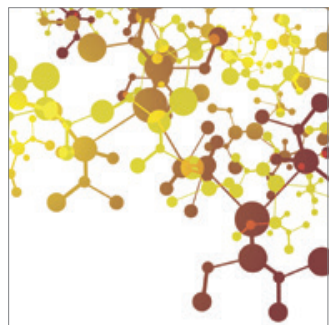

Applied Chemistry
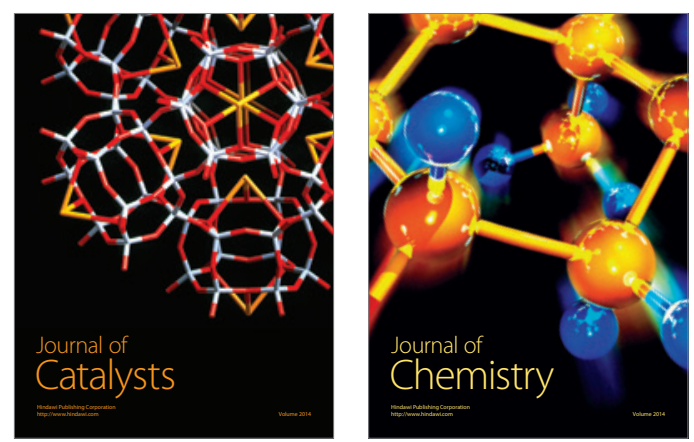
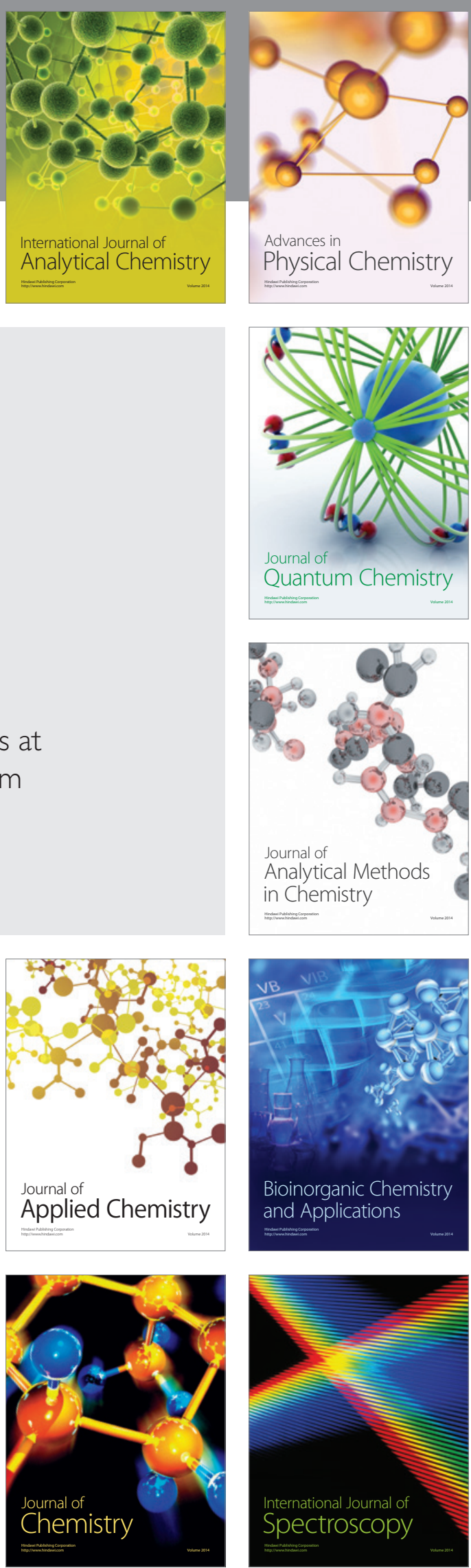